\title{
Status of Professional Skills in MBA Graduates, Its Challenges, and Way forward in Kathmandu Valley: Evidence from Professional Skill Index
}

\author{
Udbodh Bhandari $^{1}$, Malati Rana ${ }^{1}$, Niranjan Devkota ${ }^{1}$, Seeprata Parajuli ${ }^{1}$, Udaya Raj Paudel ${ }^{1}$ \\ Quest International College, Pokhara University, Gwarko, Lalitpur, Nepal \\ E-mail: niranjandevkota@gmail.com
}

\begin{abstract}
Today's MBA courses are continuous preparation-based teaching-learning practice to meet the requirements that industries expect from MBA graduates and further enhance their skills and knowledge that would aid them to fit in the job market. Thus, this study tries to assess the status of professional skills in MBA graduates, its challenges, and the way forward with the help of a professional skill index. Based on descriptive analysis, this study is conducted among 280 employers who employ MBA graduates, and a structured questionnaire was applied to collect information. The purposive sampling method was used to select the samples of 280 . The study is conducted in Kathmandu valley as many MBA colleges and banks, finance companies, insurance companies, industries, and many private companies are located in Kathmandu valley. So, the graduates also choose Kathmandu valley in the maximum number to pursue their further career. The study's findings revealed that professional skills are generally looked up into hard skills and soft skills, and $100 \%$ of organizations look for professional skills possessed by candidates while hiring them. However, they give $100 \%$ attention to soft skills possessed by MBA graduates and $99.2 \%$ attention to hard skills possessed. In soft skills, an organization thinks communication skills are must by graduates, whereas they prioritize typing skills hard skill. Therefore, this study concludes that MBA students and colleges should focus on enhancing graduates' communication skills. Likewise, being in today's computerized business world typing skill is a must for graduates. Finally, MBA graduates must develop professional attributes among themselves to fit in today's job market.
\end{abstract}

Keywords: MBA graduates, professional skills, hard skills, soft skills, organizations, hiring process, Kathmandu valley.

\section{How to Cite}

Bhandari, U., Rana, M., Devkota, N., Parajuli, S., Paudel, U. R. (2021). Status of professional skills in MBA graduates, its challenges, and way forward in Kathmandu Valley: evidence from professional skill index. International Journal of Finance Reseach, 2(1). 24-37. DOI : https://doi.org/10.47747/ijfr.v2i1.304.

\section{Introduction}

People's desire for a higher education standard in the world is proliferating (Hazelkorn, 2015). Every year higher education institutions are added, and graduates are increasingly admitted. The increasing number of graduates is devoted to the quality and value of higher education and higher education institutions give the capacity for employment of graduates or selfinitiatives. There are thousands of MBA graduates yearly (Mabey \& Thomson, 2000). Given the sparse analysis of leadership capacity in the MBA program, it is not shocking that the MBA students do not have the same abilities (Ghannadian, 2013; Devkota et al., 2021). This lack of soft skills has financial consequences for employers. For example, a soft skills deficit 
in the UK (Hurrell, 2016) could have a damaging effect on the UK economy (Clarke, 2016; Beenen, Pichler, \& Davoudpour, 2018).

Training is defined by learning experience as a planned process to change attitudes, knowledge, or skills to achieve efficient performance in various activities. Further, according to Sabir et al. (2019), learning is defined as a change in an employee's permanent behaviour due to direct and indirect work experience. Therefore, soft-talents training can be construed as a systematic process through which soft talents in an individual are developed. Soft skills cannot be taught but can only be developed by training and human capital management, and skills management (Choudary \& Ponnuru, 2015). With the recent move from the job market to current role-and-trust and career management skills, the higher education research \& development skills needed to handle the workforce proactively and successfully manage the career-building process based on lifelong learning and adaptability. Nevertheless, the capacity for student career development in universities (Watts, 2017) remains unrealized mainly, and many universities continue to remain unfulfilled in this regard.

It is relatively easy to train new graduates when they acquire the necessary qualifications at college. On the other hand, even if they are so necessary for working lives, soft qualifications, generally known as "manager skills," are not quickly learned. Usually, these abilities can be classified into three major categories: personal qualities, leadership capacity and problem management, and decision-making (Shakir, 2009). In terms of personal and professional development, diplomas, directly and indirectly, impact their knowledge and skills gained from the MBA program. The progress of technology means that the people participate in different questions and issues on the international market and the company's business success (Buenviaje et al., 2016). A person must have transferable skills to make them 'employable.' In addition to sound technical understanding and experience, managers also specify the number of skills from an employee they like (Paudel et al., 2018). It is like teamwork, problemsolving, self-management, business knowledge, post-coordination literature and numeracy, ICT knowledge, the ability to use one's initiative, and follow instructions and leadership skills where necessary (Gowsalya \& Kumar, 2015).

Most business people and companies in Nepal think that an individual should receive an MBA to advance his career. Nevertheless, commercial schools are using traditional instruments like case studies, workshops, documentaries, and talks (Devkota et al., 2021). However, theories are not usually practiced in real life. MBA students in Nepal know a lot but cannot put it into practice. Therefore, the study in the field of employee's perception towards the need for professional skills in MBA graduates is required in the Nepalese context. It is the first study in this field in the context of Nepal. It covers the set of professional skills needed for the MBA graduates necessary in the corporate world. These skills consist of communication skills, leadership skills, problem-solving skills, risk-taking skills, decision-making skills, and so on. This study will be beneficial for both employers and MBA graduates as it helps the employer locate the MBA graduates in the Kathmandu Valley and know the level of performance. Similarly, MBA graduates will also know what skills they need to get a job in the market.

Further, this study is organized as: the second section covers the research method followed by the literature review in the third section and the result and discussion in the fourth section. Finally, section five concludes the study.

\section{Literature Review}


This section includes concept of professional skills, employers' perception towards the need of professional skills in MBA graduates in Nepal, current status, and importance in organizations.

\subsection{Concept of Professional Skills}

Various researches have been done on the professional skills needed in the students before going to the market. We all know how importance is this for the students as well as for other people. However various researchers have given various definitions and opinions towards it. Professional characteristics are included in the professional values and attitude. It has enlisted various skills which are very much important in professional life (Paudel et al., 2018). They are communication skill, problem solving skill, decision making skill, team work skill, etc. (Wessels, 2005). Further, professional skills are those which help in proper utilization of resources and increasing personal as well as organizational capability (Bhatt \& Grover, 2005). Moreover, professional skill is a set of competency knowledge and capabilities that people have and utilize in their professional life (Walker et al., 2009). In addition, professional skill are those skills which are acquired to enhance the knowledge and capabilities so that people can improve their performance, increase confidence, have greater understanding of their task and responsibility (Wabule, 2016). Furthermore, professional skills convert people from novice to expert as they go through different stages (Walker et al., 2009). Here, it can be concluded that professional skills are the set of skills which help to increase your capabilities and knowledge and thus improve performance by optimum utilization of resources and brings benefits for individual as well as organization.

\subsection{Development of Professional Skills in Students}

In the development of professional skills, the method LBD (Leadership by Design) and the KJ system (sometimes referred to as affinity diagrams) were modified to an iterative approach. This LBD technique uses scientific papers to define and deliver trustworthy findings by identifying new links between existing knowledges (Mahasneh \& Thabet, 2016). Moreover, a Japanese technique that organizes a wide range of ideas or themes into a connective structure, using cards / sticky notes is an $\mathrm{KJ}$ process that makes decision and solves problems (Mahasneh \& Thabet, 2016). The KJ technique was updated to be used in the LDB (Logical Database) process as a tool.

\subsection{Types of Professional skills}

Hard skills generally require specific processes or realistic activities in the working environment that are ideally easy to observe, calculate and evaluate. On the other hand, even though soft skills are very important in working life, which are usually called people's skills, are not easily taught. Such qualities can usually be classified into three main categories: personal attributes, leadership talents, and knowledge for problem solving and decisionmaking. In this sense, hard and soft skills are complementary (Shakir, 2009). Regarding types of professional skills, 'communication skill' is a people's need, which is expressed by keeping good eye contact, showing a different vocabulary and tailoring the language to your audience, listening efficiently, presenting ideas, communicating well and concisely, and working well within a community (Aliu \& Aigbavboa, 2019). In the similar manner, 'critical thinking and problem-solving skill' can be defined as the experience that students should be able to recognize it to apply expertise intellectually, creatively, innovatively, and analytically. Under this dimension, the ability of the graduates to recognize and evaluate complex situations and

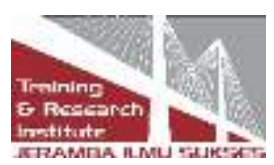


to make justifiable decisions is important. Similarly, 'team work skill' is the attributes in collaboration that include the ability to work, communicate and achieve a common objective for people from different backgrounds. Occasionally, the role of a member and community participant is required to be shared by students (Shakir, 2009). Further, in the context of 'leadership skill', Seetha (2014) argues that graduates also need to be able to understand and share the position of a leader and group member. Furthermore, Hairi et al. (2011) contends that 'entrepreneurship skill' is the capacity to recognize organizational behaviours and to design, build and analyze business plans leading inevitably to self-employment.

\subsection{Skills Seeking by the Organizations}

Substantial consideration is given to the relevant work experience and qualifications of MBA students in the job selection process. Investment in advanced education is therefore important to adapt the competences to the need for jobs (Brunner et al., 2018). New pupils must be fully-equipped with knowledge and expertise with a growing number of employees, and great emphasis should be placed on their educational accomplishments in their respective fields (Fernando et al., 2016). In this sense, students should focus actively on improving personal skills like ethical behaviour, self-motivation, teamwork, and communication skills (Suleman \& Laranjeiro, 2018). Further, knowledge and ideals, synonymity with jobs, have to continuously be improved as they are of tremendous benefit for employment (Ruge \& McCormack, 2017). The transition by the students of the MBA program of learned knowledge and abilities to their respective jobs is equated to an increased engagement of continuous learning and work-related skills, which are important factors of productivity and efficiency. We become an important part of the knowledge-based society that leads to the social well-being of their workers and people (Buenviaje et al., 2016).

\section{Method}

\subsection{Study Area}

Province 3, Nepal was taken as the area of the study. Most big organizations, business houses, and financial institutions are located in Kathmandu Valley. Kathmandu valley is enriched with 28 commercial banks, nine development banks, 18 finance companies, eight microfinance companies, Balaju industrial and Patan Industrial estates, and many private companies. In addition, $36 \mathrm{MBA}$ colleges affiliated with different universities are also located in Kathmandu valley. Maharjan et al. (2020) have asserted that two types of MBA studies are being offered in Kathmandu valley, first, they are affiliated with domestic universities and others are affiliated with international universities. Therefore, Kathmandu valley is the principal city where most MBA graduates look for a job after completing their studies, so Kathmandu valley is chosen as a study area.

\subsection{Population and Sample}

Employers or organizations hiring MBA graduates from different Kathmandu valley colleges were considered the population of the study. However, the following formula was used to determine the sample size for the study as $\mathrm{n}_{0}=\left(\mathrm{z}^{2} \mathrm{PQ}\right) / \mathrm{l}^{2} \quad$ (Cochran et al., 2004).

Where, $\mathrm{n}_{0}=$ sample size required for study, Standard tabulated value for $5 \%$ level of significance $(\mathrm{z})=1.96, \mathrm{p}=$ Prevalence of need of professional skills for MBA graduates of $50 \%=0.5$, Allowable error that can be tolerated $(\mathrm{e})=5 \%$. However, if the allowable error that can be tolerated $(\mathrm{e})=6 \%$. In calculation, $\mathrm{n}=(1.96)^{2} \times 0.5 \times 0.5 /(0.06)^{2}$ that results total

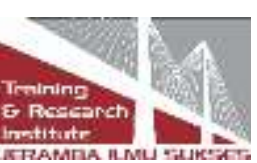


266.78 respondents. We also added $6 \%$ non-response error $6 \%$, i.e., $266.78 * 6 / 100$ (i.e., 13.34). Thus, adding all these results, the representative sample should be $(266.78+13.34)=$ $280.12(\approx 280)$. Therefore, 280 was considered a sample for this study and for the selection of this sample, the purposive sampling method, was used.

\subsection{Study Design and Data Collection Instruments}

A descriptive research design is used for the study. Both primary and secondary data were collected and used to make the study more effective. Primary data were collected with the help of a structured questionnaire, whereas secondary data were collected from different journals, articles, books, websites, which aided in literature generation.

\section{Result and Discussion}

\subsection{Socio-Demographic Analysis}

. In this study, the study covers the response of $53 \%$ female respondents and $47 \%$ male respondents. Likewise, $62.5 \%$ of respondents were between the ages of 25-35 years, i.e., youths and those at the peak of seeking job. Similarly, the age of the respondents representing below $25,35-45$, and above 45 is $15 \%, 62.5 \%$, and $1.4 \%$, respectively.

Education level is most important in the organization, especially, for people seeking a good company/organization for job. The study found that $55.3 \%$ of respondents had an intermediate level of education, $40.35 \%$ of interviewees had a bachelor level of education. In contrast, only $4.28 \%$ had Master's and above level of education. Regarding the organization type, most $(55.71 \%)$ of the respondents are from the bank, and financial institution, followed by the service sector $(38.57 \%)$, others $(2.85 \%)$, school-colleges $(1.78 \%)$, and only $0.35 \%$ represents insurance companies. As many MBA students are attracted to banking than other sectors, the banking sector at maximum level can be relevant for the study. In such circumstances, a faculty cannot achieve its college objectives for students' intellectual and personal development, it needs to work together with other people who work with students where students spend most of their time (Banta \& Kuh, 1998).

\subsection{Requirement of Professional Skills in MBA Graduates}

The study revealed that $99 \%$ of respondents hire MBA graduates in their organization, which also shows the scope of MBA graduates in different organizations. In this context, Benjamin and O'reilly (2011) have argued that MBA programs typically focus on the skills required by general managers but are unaware of those required by their graduates to succeed in their early careers. Thus, it can be said that organizations are ready and motivated to hire MBA graduates if they meet the requirements and competencies. In this sense, as the businesses are proliferating, employers are searching for employees with multiple skills and knowledge, they seek knowledge and skills in the employee so that they can grow business to the next level and improve the employability and capability of the business seniors (Robles, 2012) Moreover, MBA offers value to both MBA graduates and the organizations that employ them. This value is based mainly on the knowledge and skills learned during the duration of the MBA program (Gupta \& Bennett, 2014). Despite these facts, one study also finds out that female undergraduates are good at developing mentality; self-awareness; ability to overcome worst circumstances; the ability to maintain equal energy in any work; communication skills; and teamwork at any given time (Ravindran \& Bandara, 2015). Now, among 280 respondents, $86.42 \%$ of respondents told that the number of MBA graduates in their organization is

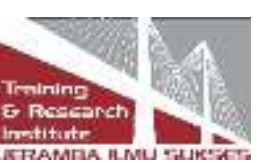


between $0-100 ; 7.5 \%$ of respondents stated the number is between $101-500 ; 3.92 \%$ of respondents told there are around 501- $1000 \mathrm{MBA}$ graduates in their organization; and remaining told that there are more than 1000 MBA graduates in their organization, which shows that organization are employing the vast number of MBA graduates, depending on the nature and size of their business and organization. Moreover, Pfeffer and Fong (2002) point out that management skills can be regarded as a core component of economic development. The study further showed that $80 \%$ of respondents hire MBA graduates as per need; $16 \%$ of the respondents hire MBA Graduates yearly; $2 \%$ of the respondents hire MBA Graduates semi-annually, etc.

\subsection{Professional Skills Index}

The study conducted on $100 \%$ of respondents exhibited that $100 \%$ of organizations seek professional skills in their candidates. Other organizations generally categorize professional skills into complex skills and soft skills. The study shows that hard and soft skills are must for all the candidates for their job. As per the surveyed organizations, $100 \%$ of soft skills are required while selecting the candidates for the job, whereas $99.2 \%$ of respondents stated hard skills are important while selecting candidates for the job. In this regard, although employers want incredibly soft skilled workforce, new workers must be hard-skilled and soft skill is mutually complementary in this regard (Robles, 2012).

Furthermore, skill-based models, knowledge, and skills have been built and are based upon three main types of skills: (1) dynamic problem-solving ability, (2) constructing abilities and (3) social judgement skills. The models recognize that knowledge and ability are dependent on the results (Mumford et al., 2017). Now, interpersonal skills, problem-solving, leadership, creativity, emotional maturity, entrepreneurial spirit, team building, professional competence, work ethics, and previous employment are among the essential employability skills frequently described in the literature (Crosling and Ward, 2002; Friga et al., 2003; Pinard and Allio, 2005; Jackson, 2010).

Table 1. Professional Skills Index

\begin{tabular}{|l|l|l|l|l|}
\hline Skills & Yes & $\%$ & No & $\%$ \\
\hline Soft Skills & & & & \\
Communication Skill & 276 & 98 & 4 & 2 \\
Teamwork Skill & 247 & 82.21 & 33 & 11.79 \\
Problem Solving Skill & 220 & 78.57 & 60 & 21.43 \\
Decision Making Skill & 168 & 60 & 112 & 40 \\
Critical Analysis Skill & 129 & 46 & 151 & 54 \\
Adaptability Skill & 130 & 46.42 & 150 & 53.48 \\
Stress Management Skill & 140 & 50 & 140 & 50 \\
Time Management Skill & 176 & 63 & 104 & 37 \\
Interpersonal Skill & 175 & 62.86 & 105 & 37.14 \\
Leadership Skill & 146 & 52 & 134 & 48 \\
Conflict Resolution Skill & 113 & 40.3 & 167 & 59.7 \\
\hline
\end{tabular}




\begin{tabular}{|l|l|l|l|l|}
\hline Hard Skills & & & & \\
Computer Skill & 177 & 63.2 & 103 & 36.8 \\
Project Management Skill & 132 & 47 & 148 & 53 \\
Typing Skill & 183 & 65.36 & 97 & 34.64 \\
Writing Skill & 97 & 34.64 & 183 & 65.36 \\
Foreign Language Skill & 36 & 13 & 244 & 87 \\
Presentation Skill & 94 & 33.6 & 186 & 66.4 \\
Coding Skill & 22 & 8 & 258 & 92 \\
Book Keeping Skill & 91 & 32.5 & 189 & 67.5 \\
\hline
\end{tabular}

Table 1 indicates the essential soft and hard skills sought by the organization while hiring any MBA graduates. The study uncovers that MBA graduates must develop numerous soft skills to be competitive in the job market. Communication skills are of prime importance as $98 \%$ of organizations look for their communication skills while hiring candidates. On the other hand, though conflict management and conflict resolution skills requirements are emerging as hot cake in the organization, only $40.3 \%$ of organizations look for this skill. Also, it is said that MBA graduates must make the critical analysis as the job market would want them to perform their tasks critically. In such circumstances, multiple findings demonstrate that improving the employability skills of recent MBA graduates will aid in closing the skill gap existing in the industry and academia (Hughes et al., 2011; Taylor and Hooley, 2014; Abrahamson et al., 2016; Agarwal et al., 2019). However, on the contrary, our study reveals that $54 \%$ of organizations do not seek critical analysis skills in MBA graduates.

Similarly, soft skills and hard skills are equally essential to be maintained by MBA graduates. The study shows that most organizations (65.36\%) look for hard skills in MBA graduates. Most of the works are based on computers and laptops, and as MBA graduates generally tend to perform officer level task organization, they make sure that they possess good typing skills. Likewise, the least of respondents $(8 \%)$ wanting complex skill for MBA graduates is a coding skill, i.e. as only a specific job would require such skill, it is not necessary for every MBA graduate. Despite a long tradition of efforts to develop classes and services that concentrate on professional skills, business people, instructors, and re-seekers continue to criticize business programming for lack of relevance to fundamental issues of industry and organization (Bennis \& O'Toole, 2005; Pfeffer \& Fong, 2002). One promising solution to the problem is to focus on a small number of fundamental skills (Butler et al., 2008).

Moreover, $87 \%$ of organizations do not think knowing a different foreign language is required for MBA graduates as Nepalese organizations use Nepali and English languages. Sound knowledge of these two languages would be enough to get into any job. Similarly, presentation skills are thought to be important skills for MBA graduates. However, $66.4 \%$ of organizations stated that they do not look for presentation skills while hiring MBA graduates. In this scenario, Bhatnagar (2020) has asserted that several factors like weak links between industry and academia, low impact research output, and a lack of freedom for MBA faculty members to introduce innovative courses cause the skill gap in MBA. 


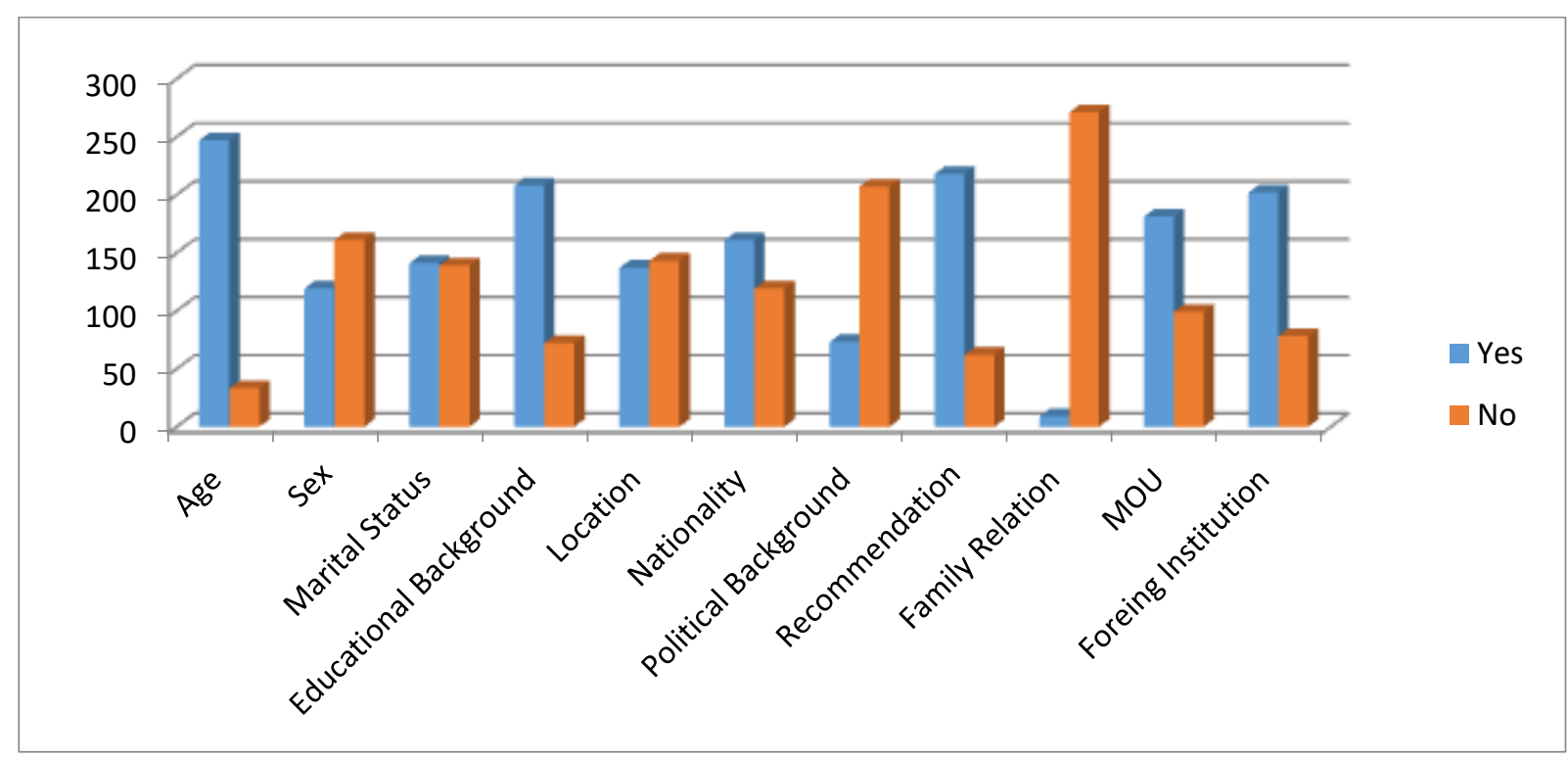

Figure 1: Link Variables and Personal Biography

\subsection{Personal Biography}

Figure 1 reveals that $88.21 \%$ of organizations consider the age factor while hiring MBA graduates. For the importance of age in handling the companies, Hill (2004) found that the average ages of 10 branch managers and nine sales managers were 36 and 30. Likewise, on a positive note, $57.5 \%$ of respondents state they do not differ between genders while selecting candidates, which means a better opportunity is provided to the potential candidates. Similarly, professional skills are analyzed by $100 \%$ of organizations while selecting the best candidates. Similarly, $72.1 \%$ of organizations revealed that they would opt for MBA graduates with foreign-affiliated institutions. $77.8 \%$ of them hire graduates based on recommendation, whereas $74.28 \%$ of respondents think educational background plays an important role while selecting candidates. Also, $96.8 \%$ of them stated that family relations are rarely considered while hiring MBA graduates. $64.64 \%$ of organizations state that the MoU (Memorandum of Understanding) they signed with colleges and institutions is also considered up to a certain extent while hiring MBA graduates.

\subsection{Challenged Faced During Hiring Process}

According to this study, $89 \%$ of respondents stated that they do not face any challenges while hiring MBA graduates, whereas $11 \%$ of organizations stated they face problems up to a certain extent. Most of the common challenges the organization faces in the hiring process are incompetent candidates, challenging to decide whom to select from a large number of applicants. Further, it takes a long process to screen data and select among a large number of applicants. Regarding such circumstances, Chia and Holt (2008) argue that business schools have seemed to be generating MBA graduates who are unprepared for the challenges of the real world.

$88 \%$ of respondents stated that problems are being faced at a moderate level followed by a low level, i.e., $9 \%$ and 3\% faced challenges at a superficial level. Also, $66 \%$ of respondents revealed a skills gap between skills MBA graduates possess and the skills that organizations want. Also, $78 \%$ of organizations stated that it is costly for an organization to provide training 
to MBA graduates after hiring them.. In this sense, taking into account about what needs to learn or want to learn and how and who learn, adult learning is affected by demography, globalization, and technology (Jowett \& Stead, 1994).

\subsection{Managerial Suggestions}

In this section, respondents responded about solving the problems they have faced and how to get the desired candidate for organizations. The managerial solutions provided by the respondents are: properly checking the skills and qualifications of the applicant and choosing the best of them $(20 \%)$; providing attractive benefits $(55 \%)$; choosing the right recruitment company (30\%); using an Applicant Tracking System (30\%); implementing and using employee referral programs (10\%); connecting colleges and university (25\%); better recruitment process and recruitment tool (65\%); creating good images of organization, hiring team should be adequately trained (45\%); involving managers and other staff during the selection process and in other decision, best use of social media organization site and other recruitment tools. $23.2 \%$ of respondents think a better recruitment process would help to solve such a problem. Likewise, only 3.57\% think applying an employee referral process would aid to solve such challenges. In this regard, McCall (2010) stated that when emerging managers struggle early on or fail to know the correct lessons from their experiences, they are less likely to lay the groundwork necessary to execute and learn from even more demanding experiences later in their careers. In such conditions, learning theory has been introduced to the principle of multiple intelligences. Learning is seen as the relationship of dozens of different functional fields, each with its strengths and weaknesses in a particular human learner (Robles, 2012). Moreover, the most frequently considered by the employers is a clear need for social skills that demonstrates the preparation and desire to develop meaningful connections with an education that employers have regularly stated their wish to share information and create students for opportunities (Bedwell et al., 2014).

The majority of the organizations think HR should be liable to solve such problems. At the same time, others departments and senior officers like managers should take responsibility for such problems. Likewise, respondents also suggested that if the organization focuses on proper selection, improvement in the hiring process, choosing media partners for the advertisement of recruitment, and using social media as a platform for recruitment, it would be better to improve its hiring process.

\section{Conclusion}

This paper aims to assess the status of professional skills in MBA graduates, its challenges, and the way forward. The acquired skills and knowledge of MBA graduates are reflected in their professional life and search for a job. Therefore, providing MBA graduates with such skills that enhance their productivity and efficiency later when they enter the corporate world should be a core responsibility that MBA colleges should take. In contrast, students should equally support them. Only then the process can be fruitful. As this study tried to analyze the professional requirement that the organization expects from MBA graduates, no organization would entertain graduates who would not possess professional skills, i.e., hard skills and soft skills. However, organizations are found to be focusing more on soft skills that graduates possess. As communication skills and typing skills are the top skills generally seen by the organization during the hiring process, MBA colleges should try to enhance the communication skills of their students along with their typing skills. Also, some organizations 
are found to have challenges at a moderate level during the hiring process, including not matching skills and not getting expected answers from the candidates. Thus, the organization should screen the applicants beforehand and only shortlist graduates match the skills that the organization require for the vacant post. Likewise, graduates should also polish themselves before going to the interview to know job requirements and descriptions and prepare themselves accordingly. Though this study tried to analyze skills required by MBA graduates, being the first of this kind of study in the Nepalese context, this study might have missed some crucial aspects that could be covered in future study. Likewise, as the study only covers Kathmandu valley, further study can incorporate other significant areas of Nepal for a more effective outcome. Also, this study was limited by 280 respondents due to various constraints, which can be increased further to make the study robust. Finally, this study only includes descriptive analysis, so future studies can be done incorporating empirical parts, representing the output more effectively to concerned parties.

\section{References}

Abrahamson, E., Berkowitz, H. and Dumez, H. (2016). A more relevant approach to relevance in management studies: an essay on performativity. Academy of Management Review, 41(2), 367-381.

Agarwal, A., Sandiford, P. and Wells, S. (2019). Exploring the 'X factor' to excavate the value of an MBA. Academy of Management Proceedings, Briarcliff Manor, NY 10510.

Aliu, J., \& Aigbavboa, C. O. (2019). Employers' perception of employability skills among built-environment graduates. Journal of Engineering, Design and Technology, 18(4), 847-864. https://doi.org/10.1108/JEDT-06-2019-0162

Banta, T. W., \& Kuh, G. D. (1998). A missing link in assessment: Collaboration between academic and student affairs professionals. Change: The Magazine of Higher Learning, 30(2), 40-46.

Bedwell, W. L., Fiore, S. M., \& Salas, E. (2014). Developing the future workforce: An approach for integrating interpersonal skills into the MBA classroom. Academy of Management Learning \& Education, 13(2), 171-186.

Beenen, G., Pichler, S., \& Davoudpour, S. (2018). Interpersonal skills in MBA admissions: How are they conceptualized and assessed?. Journal of Management Education, 42(1), 34-54.

Benjamin, B., \& O'reilly, C. (2011). Becoming a leader: Early career challenges faced by MBA graduates. Academy of Management Learning \& Education, 10(3), 452-472.

Bennis, W. G., \& O’Toole, J. (2005). How business schools have lost their way. Harvard business review, 83(5), 96-104.

Bhatnagar, N. (2020). Employability and skill gap among MBA graduates in India: a literature review. Industrial and Commercial Training. 53(1), 92104. https://doi.org/10.1108/ICT-10-2019-0098

Bhatt, G. D., \& Grover, V. (2005). Types of information technology capabilities and their role in competitive advantage: An empirical study. Journal of management information systems, 22(2), 253-277. 
Buenviaje, M. G., Encio, H. A., Refozar, R. F., Anuran, A., Camello, N. C., \& Laguador, J. M. (2016). Employability skills of MBA Graduates from literature Review as input to Student Development Program. Journal of Research in Business and Management Volume, 4(5), 16-21.

Butler, D., Johnson, L., \& Forbes, B. (2008). An examination of a skills-based leadership coaching course in an MBA program. Journal of Education for Business, 83(4), 227232.

Chia, R., \& Holt, R. (2008). The nature of knowledge in business schools. Academy of Management Learning and Education, 7. 471- 486.

Choudary, D. V., \& Ponnuru, M. (2015). The Importance Of Soft-Skills Training For Mba Students And Managers. Abhinav International Monthly Refereed Journal of Research in, 4(11), 6-14.

Cochran, S. D., Ackerman, D., Mays, V. M., \& Ross, M. W. (2004). Prevalence of nonmedical drug use and dependence among homosexually active men and women in the US population. Addiction, 99(8), 989-998.

Crosling, G. and Ward, I. (2002). Oral communication: the workplace needs and uses of business graduate employees. English for Specific Purposes, 21(1), 41-57.

Fátima, Suleman, Ana, Maria, and Costa, Laranjeiro, (2018) "The employability skills of graduates and employers' options in Portugal: An explorative study of anticipative and remedial strategies", Education + Training, 60(9), 1097-1111, https://doi.org/10.1108/ET-10-2017-0158

Fernando, M., Almeida, S., \& Dharmage, S. C. (2016). Employer perceptions of migrant candidates' suitability: the influence of decision-maker and organisational characteristics. Asia Pacific Journal of Human Resources, 54(4), 445-464.

Friga, P.N., Bettis, R.A. and Sullivan, R.S. (2003). Changes in graduate management education and new business school strategies for the 21 st century. Academy of Management Learning \& Education, 2(3), 233-249.

Ghannadian, F. F. (2013). What Employers Want, What We Teach. BizEd: The Leading Voice in Business Education. Retrieved from http:/www.bizedmagazine.com/features/articles/ what-employers-want-what weteach.asp

Gowsalya, G., \& Ashok Kumar, M. (2015). Employability skill: A literature review. International Journal of Advanced Research in Computer Science and Management Studies, 3(3), 353-360.

Gupta, A., \& Bennett, S. E. (2014). An empirical analysis of the effect of MBA programs on organizational success. International Journal of Educational Management. International Journal of Education Management, 28(4), 451-460.

Hairi, F., Toee, M. N. A., \& Razzaly, W. (2011, November). Employers' perception on soft skills of graduates: A study of Intel elite soft skill training. In International Conference on Teaching \& Learning in Higher Education, 8 (3),1-8.

Hazelkorn, E. (2015). Rankings and the reshaping of higher education: The battle for world-

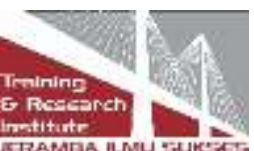


class excellence. Springer.

Hill, L. A. (2004). New manager development for the 21st century. Academy of Management Perspectives, 18(3), 121-126.

Hughes, T., Bence, D., Grisoni, L., O'regan, N. and Wornham, D. (2011). Scholarship that matters: academic-practitioner engagement in business and management. Academy of Management Learning \& Education, 10(1), 40-57.

Hurrell, S. A. (2016). Rethinking the soft skills deficit blame game: Employers, skills withdrawal and the reporting of soft skills gaps. Human Relations, 69(3), 605-628.

Jackson, D. (2010). An international profile of industry-relevant competencies and skill gaps in modern graduates. The International Journal of Management Education, 8(3), 2958.

Jowett, V., \& Stead, R. (1994). Mentoring students in higher education. Education+ Training. $36(5), 20-26$.

Mabey, C., \& Thomson, A. (2000). The determinants of management development: The views of MBA graduates. British Journal of Management, 11, S3-S16.

Maharjan, S., Devkota, N., Paudel, U. R., Bhandari, U., \& Adhikari, K. (2020). MBA graduates' perception on job search sources: Evidence from Nepal. Asian Journal of Economics, Business and Accounting, 16(3), 30-40.

Mahasneh, J. K., \& Thabet, W. (2016). Developing a normative soft skills taxonomy for construction education. J Civil Eng Architect Res, 3 (5), 1468-86.

Clarke, Mary (2016),"Addressing the soft skills crisis". Strategic HR Review, 15 (3), 137 139

Devkota, N., Adhikari, B., Paudel, U. R., Adhikari, D., Parajuli, S., \& Adhikari, K. (2021). Status of Nepalese Education Institution on Technical Adaption in COVID-19 Pandemic: An Index Based Analysis. South Asian Journal of Social Studies and Economics, 10(4), 7-19.

McCall, M. W. (2010). Recasting leadership development. Industrial and Organizational Psychology, 3(1), 3-19.

Mumford, M. D., Todd, E. M., Higgs, C., \& McIntosh, T. (2017). Cognitive skills and leadership performance: The nine critical skills. The Leadership Quarterly, 28(1), 2439.

Paudel, U. R., Devkota, N., Ghale, B. A., \& Adhikari, K. (2018). Communication and gender in bachelor's degree students' adjustment process: A study in Kathmandu, Nepal. Journal of Education, Society and Behavioural Science, 27(4), 1-9.

Pfeffer, J., \& Fong, C. T. (2002). The end of business schools? Less success than meets the eye. Academy of management learning \& education, 1(1), 78-95.

Pinard, M.C. and Allio, R.J. (2005). Improving the creativity of MBA students. Strategy \& Leadership, 33(1), 49-51.

Ravindran, K., \& Bandara, C. M. Y. S. S. (2015). factors affecting acquisition of soft skills 
and the level of soft skills among university undergraduates (With Special Reference to Management Students of the Rajarata University of Sri Lanka.

Robles, M. M. (2012). Executive perceptions of the top 10 soft skills needed in today's workplace. Business communication quarterly, 75(4), 453-465.

Ruge, G., \& McCormack, C. (2017). Building and construction students' skills development for employability-reframing assessment for learning in discipline- specific contexts. Architectural Engineering and Design Management, 13(5), 365-383.

Sabir, F. S., Maqsood, Z., Tariq, W., \& Devkota, N. (2019). Does happiness at work lead to organizational citizenship behaviour with mediating role of organizational learning capacity? A gender perspective study of educational institutes in Sialkot, Pakistan. International Journal of Work Organisation and Emotion, 10(4), 281-296.

Seetha, N. (2014). Are soft skills important in the workplace?-A preliminary investigation in Malaysia. International Journal of Academic Research in Business and Social Sciences, 4(4), 44.

Shakir, R. (2009). Soft skills at the Malaysian institutes of higher learning. Asia Pacific Education Review, 10(3), 309-315.

Taylor, A.R. and Hooley, T. (2014). Evaluating the impact of career management skills module and internship programme within a university business school. British Journal of Guidance \& Counselling, 42(5), 487-499.

Wabule, A. (2016). Continuous professional development: What role and who benefits? Reflections on teacher development in Uganda. Africa Education Review, 13(3-4), 141-156.

Walker, I., Tsarenko, Y., Wagstaff, P., Powell, I., Steel, M., \& Brace-Govan, J. (2009). The development of competent marketing professionals. Journal of Marketing Education, 31(3), 253-263.

Watts, R. (2017). Public universities, managerialism and the value of higher education. Palgrave Macmillan UK.

Wessels, P. L. (2005). Critical information and communication technology (ICT) skills for professional accountants. Meditari accountancy research.

\section{Copyrights}

Copyright for this article is retained by the author(s), with first publication rights granted to the journal.

This is an open-access article distributed under the terms and conditions of the Creative Commons Attribution license (http://creativecommons.org/licenses/by/4.0/) 